\title{
Ethics guidelines on COVID-19 triage-an emerging international consensus
}

\author{
Susanne Joebges and Nikola Biller-Andorno ${ }^{*}$ (D)
}

Keywords: COVID-19, Pandemic, Triage, Ethics

\section{Introduction}

COVID-19-classified as a pandemic by the WHO on March 11, 2020-is expected to put tremendous strain on many healthcare systems. Early epidemiological analyses show that compared to the seasonal flu, COVID-19 patients may require ventilation much more frequently [1]. This can lead to a shortage of ventilators and intensive care resources, resulting in limited medical care and death [2]. Whereas some countries have been exposed very early [3], others had the opportunity to prepare for the ethical challenges that emerge when intensive care resources become scarce.

In everyday medical practice, ventilation may be withheld or withdrawn if it is not or no longer indicated or against a patient's will [4]. In crisis situations, such as pandemics, this practice is superimposed by an additional triaging process. Medical factors of triage recommendations typically contain exclusion criteria, a mortality assessment (e.g., Sequential Organ Failure Assessment (SOFA) score), and a reevaluation requirement [2]. Beyond the medical aspects, however, triaging unavoidably involves moral choices. The main ethical considerations for making such choices concern equity and maximizing benefits $[5,6]$. Other criteria such as considering life stages, rewarding prosocial behavior, or giving priority to the worst off have been subject to long-standing controversy $[5,7,8]$.

\section{Ethics guidelines on COVID-19 triage-a synopsis} Over the past few weeks, a number of triaging guidelines have been issued in various countries, including Italy,

\footnotetext{
* Correspondence:

Institute of Biomedical Ethics and History of Medicine, University of Zurich, Winterthurerstrasse 30, 8006 Zurich, Switzerland
}

Switzerland, Austria, Germany, the UK, and Belgium. The table provides a synopsis of the key aspects that are being covered (Table 1). For the purposes of this synopsis, we have chosen to limit ourselves to guidelines of European countries that are available in English or German (cf. https://prioritiesinhealth.org/guidelines).

All guidelines (Table 1) concur that in a situation of scarcity, COVID and non-COVID patients should be treated equitably according to the same criteria [9-14]. However, no guideline argues in favor of a lottery or a "first come, first served" approach. Rather, prognosisassessed in accordance with current intensive care standards-is seen as an indispensable precondition for maximizing benefit. There is some difference between the guidelines as to the role of short-term vs. long-term survival. Whereas some guidelines $(\mathrm{CH}, \mathrm{A})$ refer to shortterm survival only as a key triaging criterion, others either do not specify survival (UK, BE) or explicitly allow for the possibility that long-term prognosis $(\mathrm{G})$ or a reduced lifespan, due to old age or to comorbidities, could affect a patient's access to a ventilator (I). In Switzerland, an age limit is rejected as a criterion in itself, yet an age of over 85 years is mentioned as an exclusion criterion to admission to the ICU if no free beds are available.

All guidelines cite the will of the patient (as expressed in person, through an advance directive or a legal representative) as guiding treatment choices. Futility is also recognized by all guidelines as a justification to end treatment even against patient will. No preferential treatment for specific subgroups is advocated, except for health staff $(\mathrm{CH})$ with a view to maintaining the workforce. Rather, fair decision-making processes are emphasized as well as good palliative care (I, CH, A, G, BE). 


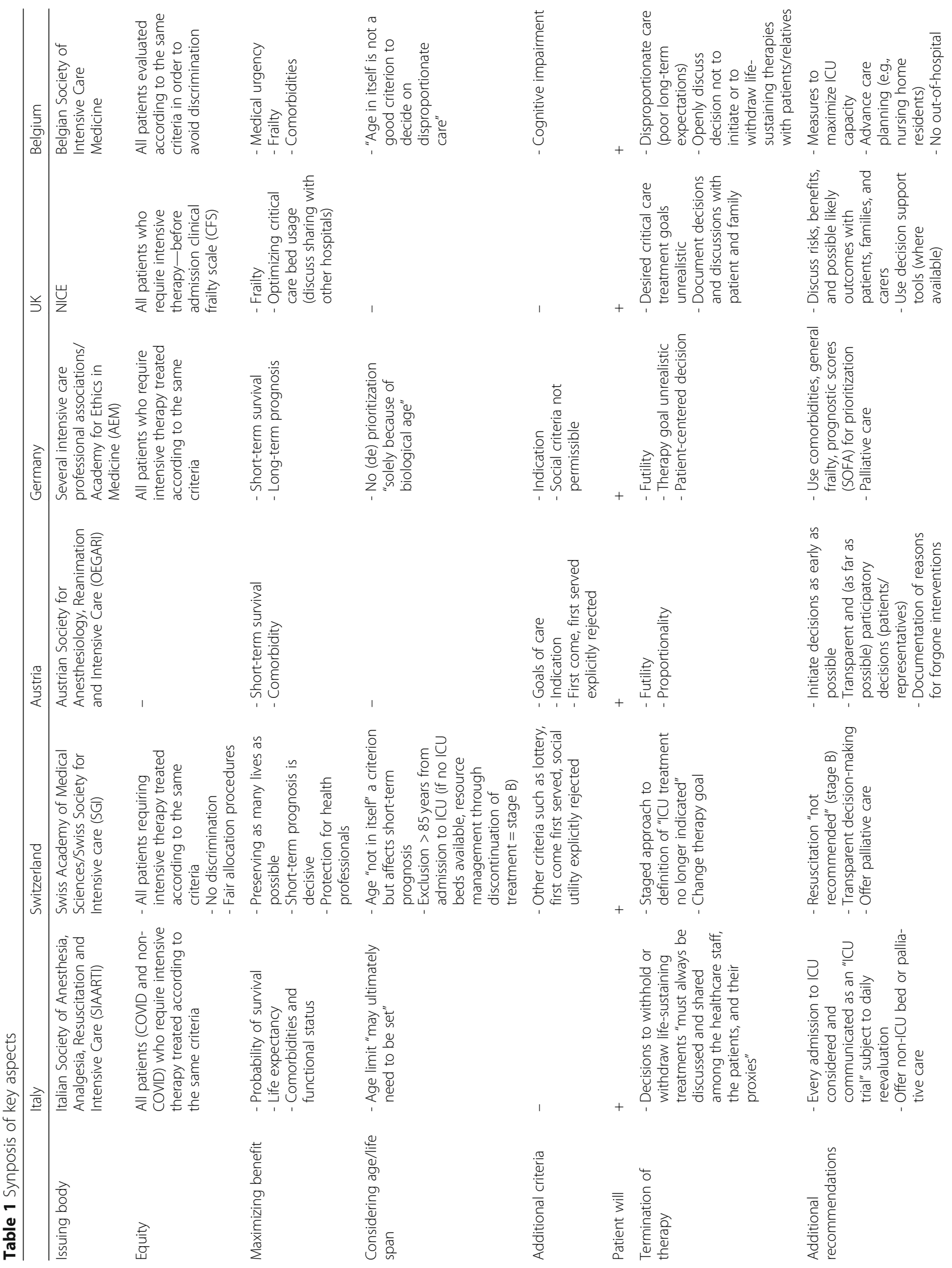




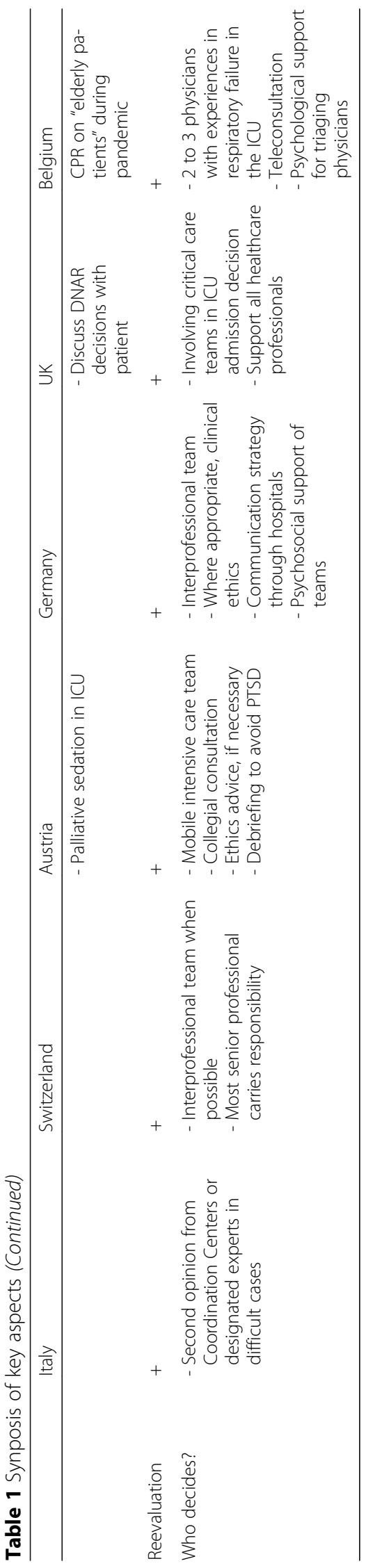


Most guidelines $(\mathrm{CH}, \mathrm{A}, \mathrm{G}, \mathrm{BE})$ call in their statements for interprofessional teams to make and document triage decisions fairly and transparently; others (I) require a second opinion in case of uncertainty. All guidelines demand regular re-evaluation of the decisions taken. In recognition of the moral stress that taking these decisions may bring on, all guidelines call for psychosocial support for health professionals.

\section{Discussion}

All guidelines have gone through intense deliberations of national associations and bodies to arrive at very similar recommendations. Respect for the patient's will, fair distribution, and maximization of benefits based on chance of survival are at the heart of the recently issued triaging guidelines. There is some disagreement as to whether only short-term survival should be considered or if more long-term considerations-life expectancy, possibly in combination with quality of life-should have a place as well. Age limits or the exclusion of other patient groups with reduced long-term survival may be very sensitive from a political and psychological point of view. It might be preferable to strengthen advance care planning, assuming that a significant number of patients with a high likelihood of poor outcomes would not opt for intensive care if other choices, such as good palliative care, were readily available to them.

Guidelines have the potential to reduce the burden on those who need to determine which patient gets access to a scarce resource. To the extent that it is unavoidable that physicians "have to decide who must die and whom (they) shall keep alive" [3], this should not happen without clear criteria that result from a consensus process of professional associations, a team approach to decisionmaking, and the offer of psychological support [9]. It will be of interest to see if artificial intelligence can play an assistive role in such situations [15].

The allocation of scarce resources has been debated within medical ethics for a long time, and procedural criteria have been defined. In order to claim moral legitimacy, the prioritization process must be transparent, inclusive (allowing for participation of all those who may be affected by decisions resulting from the process), evidence-based, and revisable in the light of new information or arguments [8]. It is encouraging to see that the consultative processes that various national bodies have gone through have yielded similar results. Whereas some differences may be due to contextual factors, the high degree of overlap inspires confidence in the robustness of the core.

Communicating these guidelines well is going to be an important task, particularly when dealing with individual patients and their families. The time constraints in developing the guidelines may have precluded a fully participatory approach, but now that a solid basis exists, it will be important to listen to the voices of all those concerned-health professionals, citizens, and other experts-to see if the status quo can be further amended and improved.

\section{Acknowledgements \\ Not applicable.}

\section{Authors' contributions}

SJ prepared the guideline synopsis, which was checked and amended by NBA. SJ wrote a first draft of the manuscript, which was revised by NBA. Both authors read and approved the final manuscript.

\section{Authors' information}

Susanne Joebges is an ethicist and intensive care physician who was involved in drafting the German guidelines.

Funding

One of the authors (SJ) received salary support from the Käthe-ZinggSchwichtenberg Fonds, Swiss Academy of Medical Sciences. The funding body had no role in the design of the study and collection, analysis, and interpretation of data and in writing the manuscript.

Availability of data and materials

Not applicable.

Ethics approval and consent to participate

Not applicable.

Consent for publication

Not applicable.

\section{Competing interests}

The authors declare that they have no competing interests.

Received: 15 April 2020 Accepted: 27 April 2020

Published online: 06 May 2020

References

1. Guan WJ, Ni ZY, Hu Y, Liang WH, Ou CQ, He JX, et al. Clinical characteristics of coronavirus disease 2019 in China. N Engl J Med. 2020:382(18):1708-20.

2. Truog RD, Mitchell C, Daley GQ. The toughest triage - allocating ventilators in a pandemic. N Engl J Med. 2020. https://doi.org/10.1056/NEJMp2005689. [Epub ahead of print].

3. Rosenbaum L. Facing Covid-19 in Italy - ethics, logistics, and therapeutics on the epidemic's front line. N Engl J Med. 2020;34(2):271-7.

4. Sprung $\mathrm{CL}$, Woodcock $\mathrm{T}$, Sjokvist $\mathrm{P}$, Ricou B, Bulow HH, Lippert A, et al. Reasons, considerations, difficulties and documentation of end-of-life decisions in European intensive care units: the ETHICUS study. Intensive Care Med. 2008;34(2):271-7.

5. Emanuel EJ, Persad G, Upshur R, Thome B, Parker M, Glickman A, et al. Fair allocation of scarce medical resources in the time of Covid-19. N Engl J Med. 2020. https://doi.org/10.1056/NEJMsb2005114. [Epub ahead of print].

6. White $D B$, Lo B. A framework for rationing ventilators and critical care beds during the COVID-19 pandemic. JAMA. 2020. https://doi.org/10.1001/jama. 2020.5046. [Epub ahead of print].

7. Daugherty Biddison EL, Faden R, Gwon HS, Mareiniss DP, Regenberg AC, Schoch-Spana $M$, et al. Too many patients ... a framework to guide statewide allocation of scarce mechanical ventilation during disasters. Chest. 2019;155(4):848-54.

8. Daniels N. How to achieve fair distribution of ARTs in 3 by 5 : fair process and legitimacy in patient selection www.WHO.int2004 [Available from: http://www.who.int/ethics/en/background-daniels.pdf. Accessed $10 \mathrm{Apr}$ 2020.

9. Vergano M, Bertolini G, Giannini A, Gristina G, Livigni S, Mistraletti G, et al. Clinical ethics recommendation for the allocation of intensive care treatments, in exceptional, ressource-limited circumstances http://www.siaarti.it: SIAARTl; 2020. [Available from: http://www.siaarti.it/SiteAssets/News/COVID19 documentSIAARTI/SIAARTI - Covid-19 - ClinicalEthicsReccomendations.pdf. Accessed 10 Apr 2020. 
10. SAMW. COVID-19 pandemic: triage for intensive-care treatment under resource scarcity. https://www.samw.ch/de.html2020. [Available from: https://www.samw.ch/de/Ethik/Themen-A-bis-Z/Intensivmedizin.html. Accessed 10 Apr 2020

11. OEGARI. Allokation intensivmedizinischer Ressourcen aus Anlass der Covid 19 Pandemie. https://www.oegariat/2020. [Available from: https://www. oegari.at/web_files/cms_daten/covid-19_ressourcenallokation_garistatement_v1.7_final_2020-03-17.pdf. Accessed 10 Apr 2020.

12. Dutzmann J, Hartog C, Janssens U, Jöbges S, Knochel K, Marckmann G, Michalsen A, Michels G, Neitzke G, Pin M, Riessen R, Rogge A, Schildmann J, Taupitz J. Entscheidungen über die Zuteilung von Ressourcen in der Notfall - und der Intensivmedizin im Kontext der COVID - 19 - Pandemie: https:// www.divi.de; 2020. [Available from: https://www.divi.de/empfehlungen/ publikationen/covid-19/1540-covid-19-ethik-empfehlung-v2/file. Accessed 10 Apr 2020.

13. NICE. COVID-19 rapid guideline: critical care in adults https://www.nice.org. uk/: NICE; 2020. [Available from: https://www.nice.org.uk/guidance/NG159. Accessed 10 Apr 2020

14. Meyfroidt G, Vlieghe E, Biston P, De Decker K, Wittebole X, Collin V, Depuydt P, Duc Nam N, Hermans G, Jorens P, Ledoux d, Taccone F, Devisch I. Ethical principles concerning proportionality of critical care during the 2020 COVID19 pandemic in Belgium: advice by the Belgian Society of Intensive care medicine - _update 26-03-2020. [Available from: http://www.siz.be/2020 Accessed 10 Apr 2020

15. Biller-Andorno N, Biller A. Algorithm-aided prediction of patient preferences - an ethics sneak peek. N Engl J Med. 2019;381(15):1480-5.

\section{Publisher's Note}

Springer Nature remains neutral with regard to jurisdictional claims in published maps and institutional affiliations. 